\title{
SZERZÖI KAPCSOLATHÁLÓ-ELEMZÉS A CSALÁDI GAZDÁLKODÁSOKRÓL SZÓLÓ PUBLIKÁCIÓK ALAPJÁN
}

\author{
Lengyel Péter - Dani Odett - Oláh Judit - Popp József - Balogh Péter -
} Füzesi István

\begin{abstract}
Absztrakt: Kutatásunk során a családi gazdálkodásról szóló cikkek szerzőinek kapcsolati hálózatát elemeztük. A kapcsolatháló elemzés definíciója alapján makro szinten tettük ezt, hiszen ez vizsgálja az egyének közötti kapcsolatokat, illetve a közöttük lévő interakciókat. A minta alapját az 1976-2016 között ebben a témában írt 254 tudományos cikk adja. A cikkben a szerzői kapcsolatokat ábrázoló hálót mutatjuk be. Kutatásunkban arra kerestük a választ, hogy miért lehet hasznos a kapcsolathálóelemzés, illetve kik a legfontosabb szereplök a hálóban.

Abstract: During our research, we analysed the social network of authors written articles on family farming. Based on the definition of the network analysis, we did this on a macro level, because it analyses the relationships between individuals and interactions between them. The sample is based on 254 scientific papers written on this topic between 1976 and 2016 . We will show you the coauthorship network. In our research, we sought to find out why network analysis can be useful and who are the most important actors in the network.
\end{abstract}

Kulcsszavak: kapcsolatháló-elemzés, családi gazdálkodás, tudományos cikk

Keywords: social network analysis, family farming, scientific article

\section{Bevezetés}

Ebben a cikkben a kapcsolati hálózatok publikációs és hivatkozási mintáit, a szerzői kapcsolatokat ábrázoló hálót mutatjuk be az elmúlt 40 évben megjelent családi gazdálkodásokról szóló tudományos cikkek alapján. A mintát az 1976-2016 között ebben a témában írt 254 tudományos cikk alkotja. Manapság egyre felkapottabbá és közkedveltebbé vált a tudományos életben a kapcsolati hálók elemzése. Mivel ez egy viszonylag új tudományterület, főleg hazai viszonylatban, nem sok kutatás foglalkozott még ilyen témával. A kutatás elején a következő hipotéziseket fogalmaztuk meg:

A legtöbbet publikáló szerzö hálózati értelemben is a legjelentősebb.

- A családi gazdálkodás témában kutató, publikáló szerzőkre is jellemző a társszerzőkkel történő közös munka.

Az elméleti áttekintés után, a módszertan fejezetben ismertetjük a kutatáshoz használt mintát, majd bemutatjuk az elvégzett munkafolyamatokat. A kutatás során kialakult eredményeket adatvizualizációval, táblázatokkal, rövid összefoglaló leíró magyarázatokkal, elemzésekkel közöljük.

\subsection{Kapcsolatháló-elemzés}

A kapcsolatháló-elemzés mikroszinten az egyének viselkedését tanulmányozza, makroszinten pedig az egyének közötti kapcsolatokat (hálózati struktúrát) és a közöttük lévő interakciót (Stokman, 2004).

A hálózatelemzés elvi alapja a szociálpszichológiai analízis, más néven a szociometria, melyet a későbbiekben más tudományágak szakemberei is 
elsajátítottak. A szociometria egyik első kimunkálója, Jacob Levy Moreno román származású pszichiáter volt. 1932-ben megjelent „Ki éli túl? (Who shall survive?)” címü müvében kezdett foglalkozni szociometriai vizsgálatokkal. Ez a kötet a késöbbi kiadások folyamán több mint 700 oldalasra nőtte ki magát és több mint 20 nyelvre fordították le „A szociometria alapjai” címen. 1937-ben publikálta önálló szaklapját, a Szociometriát (Mérei, 2006). Ezekre az alapokra építve jött létre a mai korszerü kapcsolati hálózat elemzés (SNA - Social Network Analysis).

Az SNA-módszertan elvi forrását Siegfried Frederick Nadel munkássága teremtette meg (Tóth, 2009). A módszertan fejlödését jócskán előmozdította a számítógépek megjelenése, a számítógépes elérhetőségek, adminisztrációs módok növekedése, a matematika fejlődése. Több területen is nagy hasznát veszik e módszerek kialakulásának, legföképp a vállalkozások összeolvadása, az innováció tovább terjedésében, a politikai, fogyasztói, piaci szereplök döntésének meghozatalában, csoportmunkák produktivitásában, betegségek terjedésében (PálVörös, 2011). Ide sorolható továbbá a szociológiai és közgazdasági kutatásokban egyre nagyobb jelentőséggel bíró társadalmi hálózatok, illetőleg ezen hálózatok révén létrejövő társadalmi tőke vizsgálata és mérése is (Kis, 2006).

\subsection{Családi gazdálkodás, családi gazdaság}

Kutatásunkban olyan szerzők közötti kapcsolathálót vizsgálunk, akik családi gazdálkodásról szóló cikkeket publikáltak. A családi gazdaság meghatározására több megfogalmazást is találtunk,

A családi gazdaság egy olyan gazdaság, amelyet egy vagy több generációt magába foglaló család birtokol és müködtet. A föld és a tőke nagy részét a család biztosítja. A munkaerő nagy részét többnyire a gazdaságban élő családtagok biztosítják, idöszakosan azonban külső bérmunka is igénybe vehető (GaleskiWilkening,1987). Takácsné és Galeski-Wilkening megfogalmazásával ellentétben Williams (1973) meghatározása kizárja a külső munkások alkalmazását, még szezonális jelleggel is. Williams véleményével ért egyet Buzás (1994) is, aki szerint nem lehet családi gazdálkodásról beszélni abban az esetben, ha az többségében alkalmazottakra, bérmunkásokra támaszkodik.

Családi gazdálkodás tekintetében hazánkban a „hagyományosabb” értelemben vett gazdálkodási formáról beszélhetünk, vagyis országunkban olyan családi gazdaságok dominálnak, ahol a munkaeröt csak a családtagok szolgáltatják, így alacsony költséggel üzemeltethető. A „modernebb" felfogásban nem csak a családtagok, hanem bérmunkások is munkát vállalnak a gazdaságban, azonban jellemzően ezek szezonális jellegüek.

\section{Anyag és módszer}

\subsection{A kutatás alapjául szolgáló minta}

A mintánkat a Scopus-ból kérdeztük le. A keresőjébe a „family farm”, valamint a „family farming" kifejezésekre szürtünk rá, mely eredményeként $254 \mathrm{db}$ találatot kaptunk. Ez a mennyiség kezelhető, feldolgozható, ezért nem szükítettük tovább a 
keresési feltételeket. A találati listát exportáltuk és a Scopus API-val kommunikáló szoftverünk adatbázisába illesztettük. A szoftver segítségével megkaptuk a cikkekhez kapcsolódó adattáblákat (cikkek, szerzők, kutatóhelyek, kulcsszavak, témák).

\subsection{Hálózatelemzés}

Az SNA módszertan, ami egy aránylag fiatal diszciplína, megfelelő ahhoz, hogy tudományos társulatok publikációs modelljeit grafikusan szemléltetve vizsgáljuk meg. Hazánkban az efféle elemzések még kezdeti stádiumban vannak, zömében csupán folyóiratokról készítettek (Popp et al., 2015). A tudománymetriában már az 1920-as években, Alfred Lotka felméréseket folytatott azzal kapcsolatosan, hogy egyes lapokban milyen megoszlásban vannak az n számú cikket kiadó szerzők. A Lotka-képlet szerint: $1 / \mathrm{n}^{2}$, az $\mathrm{n}$ számú publikáció tulajdonában lévő szakember aránya. A szerzök társulásának több oka is lehet, olyanok, mint például: szerveződési okok, laboratóriumi berendezések elérhetősége, nagyobb pénzügyi finanszírozást igénylő beruházások, eljárások felgyorsítása, hibák mérséklése, termelékenység növelése (Micsinai, 2011). A társszerzős kiadványoknál Yoshikane (2006) szerint két különbözö funkció figyelhetö meg, a vezetö és a követö. A vezető az a személy, aki az írásban elsőként kerül megjelenítésre. Korábbi kutatások feltárták, hogy ezeknek a fajta kooperációs cikkeknek a növekedése hatással van az egyéni teljesítményre, ezáltal a saját produktivitás is egyidejüleg gyarapodik (Glänzel, 2002).

Elmondható, hogy egy témakörön belül publikáló szerzői csoportok vagy egyedül publikálók is tekinthetőek egy kapcsolati hálóként, ahol a kapcsolatot a szerzők közötti együttmüködések jelentik. A kapcsolati adatok ábrázolásának és elemzésének legjelentősebb módszere a gráfelmélet. Ez az eljárás azért praktikus, mert megvan a megfelelő szókincse a kapcsolatháló-alakzatok bemutatására, valamint matematikai alapot biztosít, hogy mérhetőek legyenek az adatok. Gráfok alkalmazásával szemléletes képet kapunk a kapcsolathálók mintájáról. Elengedhetetlen leszögezni, hogy gráfok megjelenítésekor a pontok pozíciója, illetve az ezeket összekapcsoló vonalak hossza nem tartalmaz információt. Ebben az esetben a vonal, pontok és élek olyan sorozatát jelöli, ahol minden él csupán egyszer jelenik meg.

A gráfelméleti szemlélet azért ideális számunkra, mert kiválóan használható a kulcsfontosságú személyek meghatározására. Kulcsfontosságú személyeknek ebben az esetben azokat az írókat tekintjuik, akik a legtöbb szerzöi kapcsolattal rendelkeznek. Ezek a meghatározó személyek a kapcsolatháló stratégiai pontjaiban foglalnak helyet (Kürtösi, 2004).

Nem irányított gráfok esetén centralitásról (központiság) beszélünk, amikor azt tartjuk fontosnak, hogy a szereplő közremüködik a kapcsolatokban, az pedig kevésbé lényeges, hogy ö a kapcsolatban küldő vagy fogadó szerepet tölt be (Kürtösi, 2004).

Az egyik ismert centralitás számítási mód a fok-centralitás (degree centrality). Ekkor az egyes pontok kapcsolatainak számát viszonyítjuk az összes kapcsolathoz. 
Központiságot számíthatunk közelség centralitással is, eszerint egy személy akkor kerül központi helyzetbe, ha az összes szereplőt egyszerủen, rövid idő alatt eléri és így nem szükséges más tagok bevonása (Kürtösi, 2004).

A következỏ centralitás számítási mód a közöttiség centralitás (betweenness centrality). Ez azon alapszik, hogy azok a szereplők a legbefolyásosabbak, akik sok másik szereplő között foglalnak helyet. Ekkor voltaképpen azokat a legrövidebb utakat kell számba vennünk, amik a közbülső pontokat magukba foglalják (Kürtösi, 2004).

\section{Eredmények és azok értékelése}

Az 1. ábrán egy világtérkép látható, amelyen az egyes pontok azt jelölik, hogy mely kutatóhelyeken jelentek meg az egyes publikációk, a számok pedig azt mutatják, hogy az adott városban hány tudományos cikk keletkezett. A kutatóhelyek városainak koordinátáit egy külön Excel munkafüzetbe mentettük, majd ezt a MapsData online alkalmazásba importáltuk. Az ábráról első ránézésre is látható, hogy a cikkek javarészt Európából és Amerikából származnak. Ez következhet abból is, hogy ezeken a földrészeken jellemző leginkább a családi gazdálkodás.

\section{1. ábra: Szerzők kutatóhelyeinek városonkénti megoszlása}

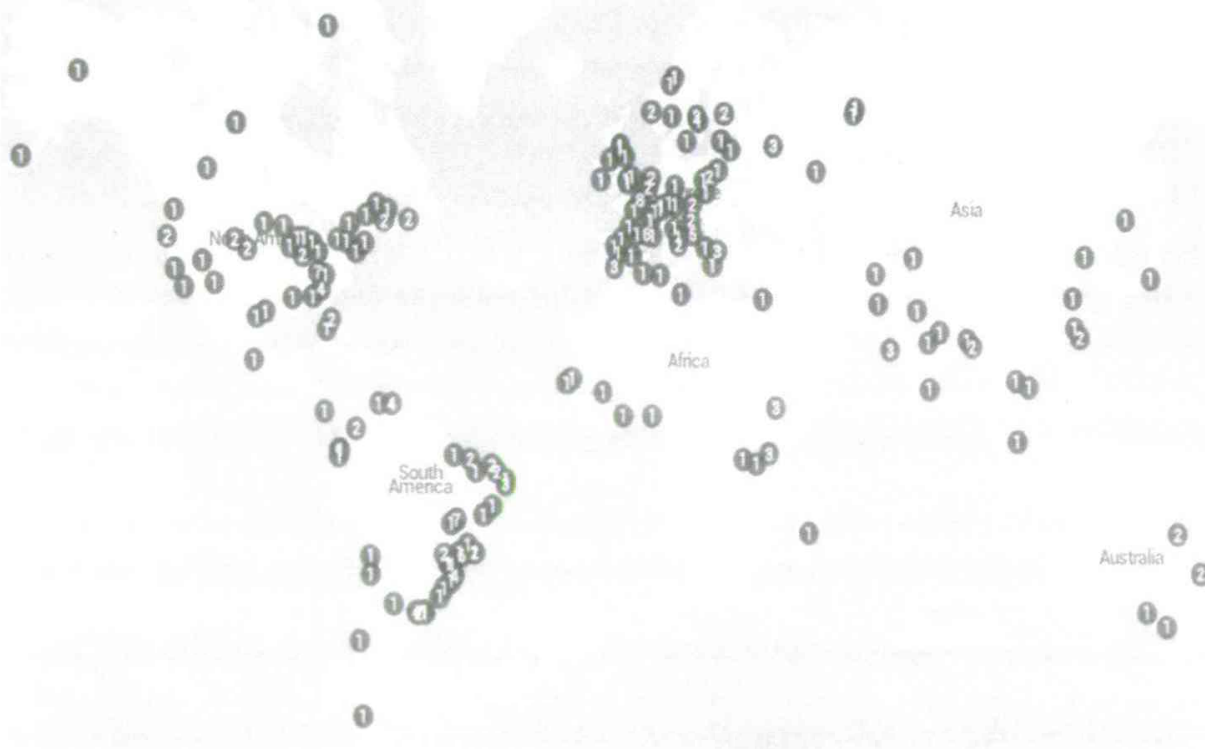

Forrás: Saját szerkesztés

\subsection{Leíró statisztikák}

A 2. ábrán a családi gazdálkodás témában készített publikációk számának évenkénti alakulása látható. Megfigyelhető, hogy családi gazdálkodásokról szóló cikkek legnagyobb részét az elmúlt években írták. Köszönhető ez annak is, hogy napjainkban, jogilag sokkal nagyobb szerepe van a családi gazdaságnak, mint 
fogalom körülhatárolásának. Főként a 2009-es évektől kezdve folyamatosan nőtt az ezzel a témával foglalkozó cikkek száma. 2015-ben 37 db cikket írtak, ami az összes megjelent cikk 15\%-át teszi ki.

\section{2. ábra: Publikációk számának évenkénti alakulása 1976-2015 között}

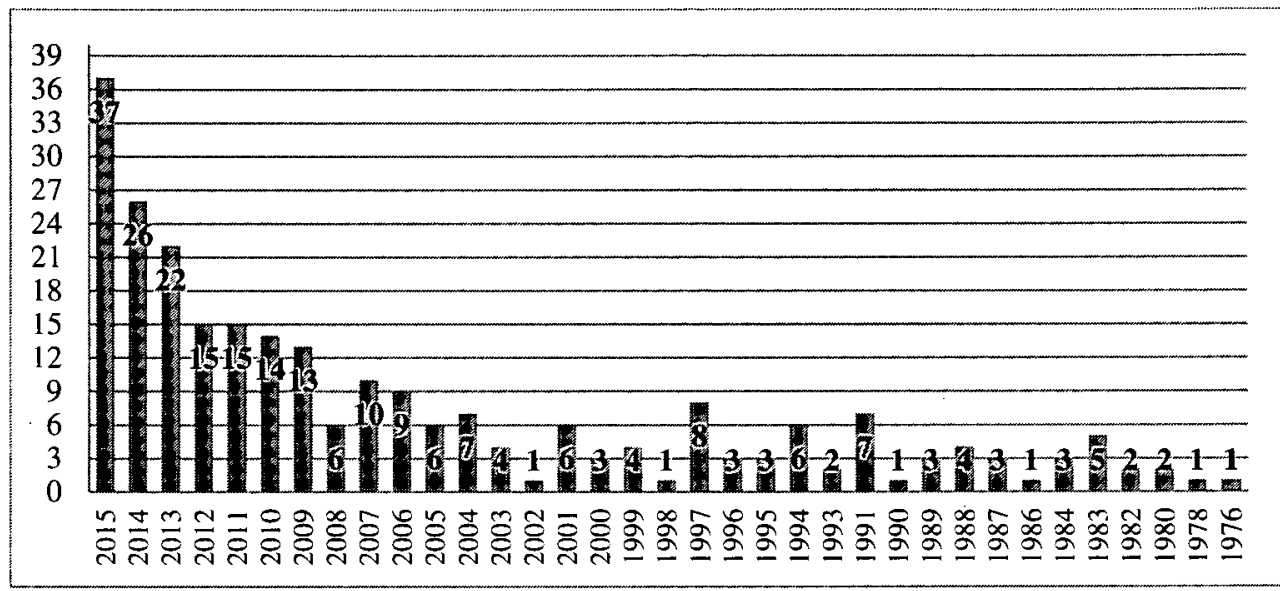

Forrás: Saját szerkesztés

Véleményünk szerint a 2014. évben megírtaknak egy része köszönhető annak is, hogy ez az év volt a családi gazdálkodás nemzetközi éve, amit az ENSZ nyilvánított ki. „A 2014-es Nemzetközi Év célja, hogy a nemzeti agrár, környezetvédelmi és szociális szakpolitikák középpontjába helyezze a családi gazdálkodást." (FAO, 2014). Az 1990-es évektöl a hazai szakirodalom is egyre többet foglalkozott ezzel az akkoriban újnak számító gazdasági formával (Magda, 2010).

A publikációk számának országonkénti megoszlását figyelhetjük meg a 3 . ábrán. A témával foglalkozó cikkek több mint 50 országból jelentek meg. Ezek közül a legtöbb Brazíliában jelent meg, a 254 cikkböl 50-et publikáltak ebben az országban. Ezt követi az Amerikai Egyesült Államok 25, majd Franciaország 22 megjelent cikkel. Az, hogy Brazíliában jelent meg az írások legtöbbje betudható annak, hogy az országban dominál a mezőgazdaság, világelső kávé-, cukornád-, narancs és banántermelésben, valamint szója, kakaó, marhahús és dohánytermelésben is élen állnak (Balogh et al., 2016). 2008-ban a brazil kormány a kisgazdák számára javasolt egy a családi gazdálkodás erősítését célzó programot (Marti, 2008). 


\section{3. ábra: Publikációk számának országonkénti megoszlása}

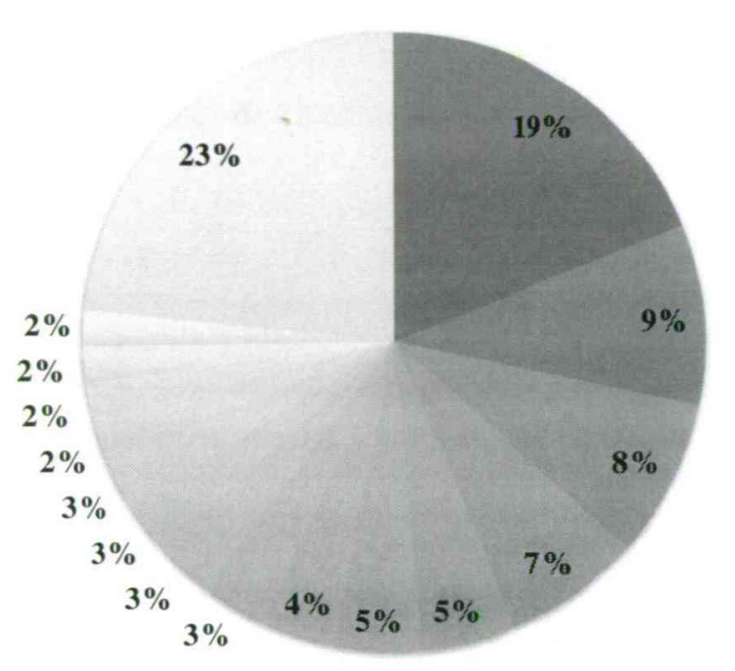

= Brazil
= United States
= France
= United Kingdom
= Australia
= Spain
= Croatia
= Canada
= Argentina
= Germany
- Italy
- Greece
Bangladesh
Poland
Sweden
Egyéb

Forrás: Saját szerkesztés

Több, mint 20 különbözö európai országból jelentek meg publikációk. Ezen országok közül legtöbb Franciaországban (22 db), az Egyesült Királyságban (19 db), Spanyolországban (12 db) és Horvátországban (10 db) jelent meg.

Az 1. táblázatból jól látható, hogy a legtöbbet publikáló író Linda Price 6 db írásával, melyből hármat egyedül, hármat pedig társszerzőkkel dolgozott ki. A hat publikációból három a nők a családi gazdaságokban betöltött helyzetével foglalkozik. Ezekben az írásokban bemutatja, hogyan értékelődött át a nők szerepe a gazdaságokban.

\begin{tabular}{|c|c|c|}
\hline Rangsor & Szerző & Publikáció száma (db) \\
\hline 1. & Price L. & 6 \\
\hline 2. & Guanziroli & 3 \\
\hline 3. & Sourisseau J.-M. & 3 \\
\hline 4. & Radinovic & 3 \\
\hline 5. & $\begin{array}{r}\text { Kasimis C. - Papadopoulos, A.G. } \\
\text { Forrás: Saját szerkesztés }\end{array}$ & 3 \\
\hline
\end{tabular}

A szerző ezekkel a cikkekkel arra próbálja felhívni a figyelmet, hogy jobban ki kellene emelni, értékelni a nők által betöltött szerepeket. A ,The Emergence of Rural Support Organisations in the UK and Canada: Providing Support for Patrilineal Family Farming" címủ publikációban, a Kanadában és az Egyesül Királyságban 1980-óta végbement mezőgazdasági szerkezet átalakulásról kapunk képet és, hogy ebben a két országban miért és miként dominálnak még mindig a családi gazdaságok. 
Megtudhatjuk, hogy szállnak a gazdaságok apáról fiúra, generációról generációra. A ,'Keeping the name on the land': Patrilineal succession in Northern Irish family farming” és a „From stress to distress: Conceptualizing the British family farming patriarchal way of life" írásokban is hasonlóan a családi gazdálkodás generációknak történő átörökítésének fontosságáról ír egyik esetben az észak írországi családok felfogásában az ottani szokások tekintetében, a másikban pedig az angol családi szokások tekintetében.

\subsection{Szerzői kapcsolatok hálózata}

A 4. ábrán a publikálók kapcsolati gráfját láthatjuk. Megfigyelhető, hogy azok a szerzők, akik egyedül, illetve ketten, hárman jelentettek meg egy cikket a periférián foglalnak helyet. Ez az ábra a modularitás mutató alapján készült. A nagyobb szerzői klikkek a centrumban helyezkednek el. 5 darab olyan viszonylag nagyobbnak tekinthető klikk van, amely tíz vagy annál több szerzőből áll össze.

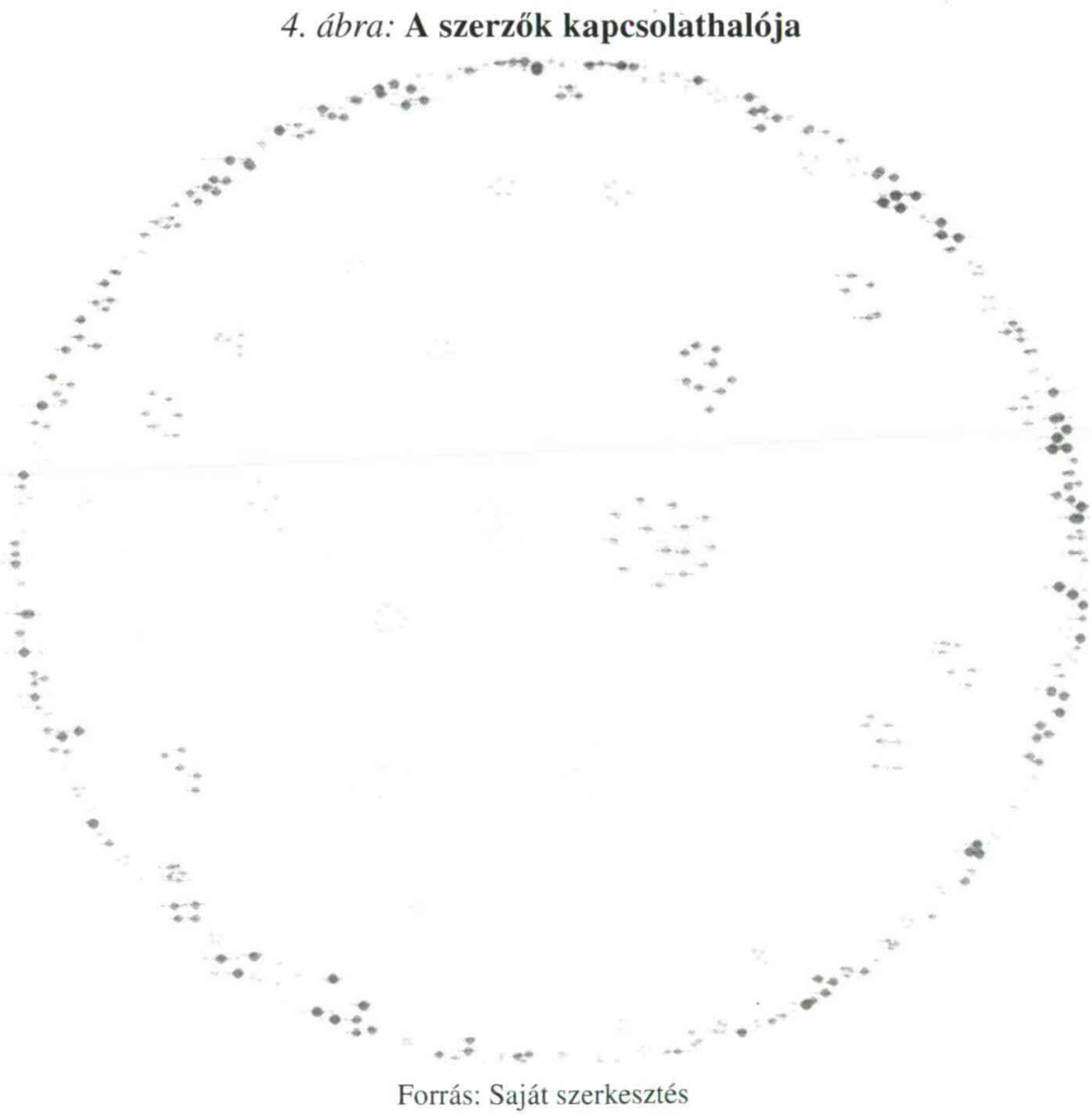


Levonható az a következtetés, hogy szoros szerzöi csoportok jöttek létre, melyekbe a belépés nehéz, illetve az egyes nagyobb csoportok között nincs kapcsolat.

\subsection{Szerzöi klikkek}

A 2. táblázat az 5 legnagyobb szerzöi csoportosulást mutatja, mely 53 főt érint. Az adattábla összesen 539 fö különböző szerzőt tartalmazott, amelyek arányában ez az 53 fő 9,8\%-ot jelent. Fontos megjegyeznünk, hogy emellett az 5 legnagyobb csoport mellett, még megtalálható több $7,6,5$, illetve 4 fős társulás is.

\section{2. táblázat: Az 5 legnagyobb szerzői klikk tagjai}

\begin{tabular}{|c|c|c|c|c|}
\hline 1. klikk & 2. klikk & 3. klikk & 4. klikk & 5. klikk \\
\hline Bodekær & Gehring & Bosc & Rozon & Van Vliet \\
\hline Harrison & Spithoven & Marzin & Lucotte & Schut \\
\hline Philipsen & Schmid & Bélières & Davidson & Reidsma \\
\hline Petersen & Bitter & Sourisseau & Sousa Passos & Descheemaeker \\
\hline $\begin{array}{l}\text { Rogowski- } \\
\text { Tylman }\end{array}$ & $\begin{array}{l}\text { Braun- } \\
\text { Fahrländer }\end{array}$ & Pédelahore & Oestreicher & Van de Ven \\
\hline Schmalwieser & Dalphin & Losch & Mertens & Slingerland \\
\hline Triguero-Mas & Hyvärinen & Bonnal & Paquet & Giller \\
\hline Dadvand & Pekkanen & Parrot & Romana & \\
\hline Lesiak & Riedler & & & \\
\hline Narbutt & Weiland & & & \\
\hline Eriksen & Büchele & & & \\
\hline Heydenreich & Mutius & & & \\
\hline Nieuwenhuijsen & Vuitton & & & \\
\hline Thieden & Brunekreef & & & \\
\hline $\begin{array}{l}\text { Young } \\
\text { Wulf }\end{array}$ & & & & \\
\hline
\end{tabular}

Forrás: Saját szerkesztés

Ez továbbmutat arra is, hogy a legtöbb szerző a mintában kisebb csoportokban vagy egyedül dolgozott. Ezen csoportok publikációi számának aránya elenyésző az összes publikációhoz képest. Ezekre a csoportokra jellemző, hogy általánosságban csupán egyszer egy cikket jelentettek meg közösen. Az 5. ábrán ezeknek a csoportoknak a gráfjai láthatóak, modularitás alapján ábrázolva. 


\section{5. ábra: Társszerzői klikkek}

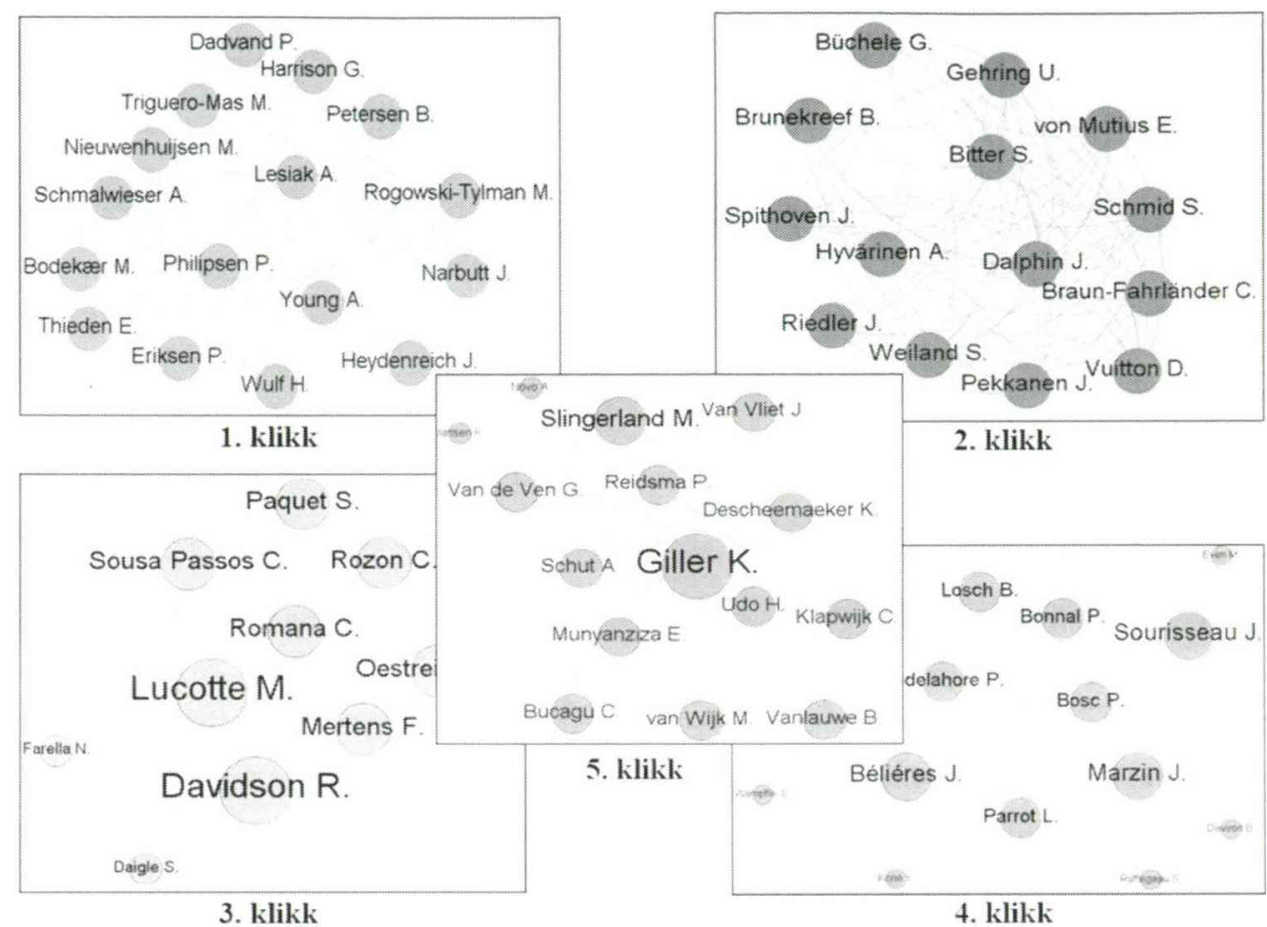

Forrás: Saját szerkesztés

Az 1. klikkröl készült gráfon jól látható, hogy ebben az esetben minden szerző kapcsolatban áll minden szerzővel. Ebben az esetben egyetlen szerző sem publikált együtt más szerzőkkel. Ugyanez a helyzet áll fenn a 2. klikk tagjainak esetében is.

A 3., 4. és 5. klikk esetében már látható, hogy nem minden szerzö áll közvetlen kapcsolatban mindenkivel. Jól kivehető, hogy például a 4. klikk esetében Jacquez Marzin-nak csak közvetett kapcsolata van példáil Even-nel, Koné-val vagy Wampfler-rel. Az 5. klikknél szintén megfigyelhetjük, hogy Novo és Jansen egymáson kívül csak Slingerland-dal áll közvetlen kapcsolatban.

\subsection{Szerzői rangsor}

Számunkra leginkább hasznos index a közöttiség centralitás, mivel az értékek ebben az esetben tértek el jelentősen egymástól, így látványos, pontos sorrend alakult ki. Megvizsgáltuk, hogy a legtöbb cikket publikáló szerzők és a közöttiség, fokszám alapján felállított sorrendek között van-e egyezés. Ezzel választ is kaptunk az első számú hipotézisünkre, amiben azt tételeztük fel, hogy a legtöbbet publikáló szerzők, hálózatos értelemben véve is a legjelentősebbek. Abban az esetben, ha a legtöbbet publikáló szerző neve megtalálható a centralitás mutatók által felállított sorrendủ oszlopban, a hipotézisünk helytálló. Ellenkezö esetben, ha a legtöbb cikket megjelentetett szerző neve nem szerepel a többi oszlop egyikében sem, az első számú feltevésünk hamisnak bizonyul. Ahhoz, hogy ezeket egyszerübb legyen áttekinteni, 
készítettünk egy összesítő táblázatot (3. táblázat), ahol együtt láthatóak az említett sorrendek.

\section{3. táblázat: Szerzői rangsorok}

\begin{tabular}{|l|c|l|c|l|c|}
\hline Cikkek száma & \multicolumn{3}{|l|}{} & Közöttiség & \multicolumn{2}{l|}{ Fokszám } & érték \\
\hline szerző & érték & szerzó & érték & szerzö & 15 \\
\hline Price & 6 & Marzin & 10 & Bodekær & 15 \\
\hline Guanziroli & 3 & Slingerland & 7 & Harrison & 15 \\
\hline Sourisseau & 3 & Giller & 7 & Philipsen & 15 \\
\hline Radinovic & 3 & Žtinić & 6 & Petersen & 15 \\
\hline Kasimis & 3 & Radinovic & 4 & Triguero-Mas & 15 \\
\hline Papadopoulos & 3 & Sourisseau & 3 & Schmalwieser & 15 \\
\hline Lucotte & 2 & Bélières & 2 & Rogowski-Tylman & 15 \\
\hline Slingerland & 2 & Pritchard & 2 & Dadvand & 15 \\
\hline Marzin & 2 & Lucotte & 1 & Lesiak & 15 \\
\hline Giller & 2 & Davidson & 1 & Narbutt & 15 \\
\hline
\end{tabular}

A 3. táblázatról első ránézésre megállapítható, hogy a legtöbbet publikáló szerzök, hálózati értelemben vizsgálva nem feltétlenül a legjelentősebbek. Fokszámok tekintetében elmondható, hogy mind a 10 szerző egyformán sokat publikált társszerzőkkel, mivel mindegyikőjük értéke 15. Ez alapján köztük nem lehet sorrendiséget felállítani. Fokszámok tekintetében kiválasztott szerzők és a legtöbbet publikálókat nézve nincs egyezés. Ez arra enged következtetni, hogy a viszonylagosan többet publikáló szerzőkre nem jellemző a társszerzőkkel való együttmüködés. Jacques Marzin közöttiség mutatója az első helyen áll, ami kiemelkedő „,közvetítő” szerepére utal. Vagyis ebben a hálózatban ő az a szerző, akit a legkönnyebb el elérni. Marzin publikációinak száma 2, ami viszonylag alacsony, azonban nem tekinthető rossznak, azt figyelembe véve, hogy nagyon szórt az adatbázis és a legtöbb szerző csupán egy-egy publikációt jelentetett meg ebben a témában. Mindkét iratot többen készítették, tehát nem egyedül publikált. Közöttiséget tekintve a következő két helyen álló szerző Maja Slingerland és Ken Giller is szintén két-két publikációt tettek közzé. Graham Harrison és Paul Eriksent leszámítva ugyanazok a nevek fordulnak elő a két oszlopban. Jacques Marzin a közelség mutatónál nem szerepel, a top 10 szerző között, ami egy kisebb, de stabilabb társszerzői hálózatra engedhet következtetni. Összességében ezen eredmények azt szemléltetik, hogy az először elvégzett megállapításokkal ellentétben a szerzök száma és a hálózatban betöltött szerepük között nincs összefüggés. Úgy látszik, hogy néhány szerző viszonylag - az adatbázis megosztottságához képest - sokat publikál kevés társszerzővel, ezzel ellentétben másoknak szerteágazóbb társszerzői kapcsolati hálózatuk van, de relatíve kevesebb cikkel rendelkeznek. 


\section{Következtetések}

A mintákban szereplő cikkek nagyjából fele-fele arányban származik Amerikából és Európából. Ebből látható, hogy a családi gazdálkodás, mint gazdálkodási forma leginkább ezen a két kontinensen tölt be jelentős szerepet. Amerikában leginkább farmgazdálkodásról beszélhetünk, amely valamelyest eltér az általunk értelmezett családi gazdálkodástól, de alappilléreiben egyezik.

A cikkek megjelenésének évszámaiból látható, hogy ez a témakör nem tekint vissza nagy múltra, viszonylag fiatal területnek számít. Számunkra meglepő eredményt jelentett, hogy a megjelent cikkek ilyen nagy arányban (44\%-ban) egyedül dolgozó szerzőtől származnak. A kutatás megkezdése elött azt feltételeztük, hogy sokkal kisebb arányban lesznek majd ilyen cikkek. Csupán néhány nagyobb szerzői csoportot fedezhetünk fel, amelyek a modularitás mutató alapján szemléltetett gráfon jól láthatóan különülnek el egymástól. Ez arra enged következtetni, hogy ezek a csoportok zártak, így nehéz a bekerülés. Ezeken a csoportokon belül azt is láthatjuk, hogy jellemzỏen olyan klikkek vannak, amelyekben minden szerző kapcsolatban áll minden szerzövel. Jellemzően egy ilyen klikk csupán egy cikket írt meg közösen.

Első számú hipotézisünk, miszerint a legtöbbet publikáló szerző hálózati értelemben is a legjelentősebb, nem nyert bizonyítást. Mivel a legtöbbet publikáló szerző Linda Price volt, azonban hálózati értelemben nem meghatározó a szerepe, sem közvetítőként, sem könnyen megközelíthetősége, sem pedig fokszámát tekintve, vagyis nem sokat publikált más szerzőkkel együtt.

Második számú hipotézisünk, hogy ezen cikkek íróira jellemző a társszerzőség, igaznak bizonyult. Ezt támasztja alá, hogy a megjelent cikkek 56\%-a társszerzők által készült, míg a cikkek kisebb arányban (44\%-ban) készültek egyéni munka folytán. Fontos azonban megjegyeznünk, hogy a nem egyedül írókra is inkább a kisebb csoportokban való tömörülés a jellemzö.

\section{Irodalomjegyzék}

Balogh P., Békési D., Gorton M., Popp J., Lengyel P. (2016): Consumer willingness to pay for traditional food products, Food Policy 61: 176-184.

Buzás Gy. (1994): A családi gazdaságok jövedelmezösége és helyük a vállalati struktúrában. Gazdálkodás, 38 (6): 25-34.

FAO (2014): 2014 a családi gazdálkodás nemzetközi éve. http://www.fao.org/docrep/019/as281hu/ as281 hu.pdf letöltés dátuma: 2016.08.04.

Galeski, B., Wilkening, E. (1987): Family Farming in Europe and America. Boulder, Colorado Westviwe Press, $1-4$.

Kis K. (2006): A társadalmi töke, mint a társadalmi és gazdasági folyamatokat befolyásoló erőforrás. Agrártudományi Közlemények, 2006/20: 69-73.

Kürtösi Zs. (2004): A társadalmi kapcsolatháló-elemzés módszertani alapjai. In Letényi László (szerk.): Településkutatás. Budapest, L'Harmattan, 663-684.

Magda S. (2000): A régiók mezőgazdaság- és vidékfejlesztése. Gazdálkodás 44 (2): 60-67.

Marti, M., A. (2008): Brazília mezögazdasága. /Feljegyzés/ Brüsszel, 17-18. http://www.europarl.europa.eu/RegData/etudes/note/join/2008/397242/1POL-

AGRI_NT(2008)397242_HU.pdf letöltés dátuma: 2016.09.03.

Mérei F. (2006): Közösségek rejtett hálózata. Osiris Kiadó, Budapest. 
Micsinai I. (2011): Társszerzői hálózatok topográfiája és dinamikája. - A Közgazdasági Szemle, a Magyar Pszichológiai Szemle, a Pszichológia, valamint a Szociológiai Szemle társszerzői hálozatainak elemzése. Szociológiai szemle. 21 (1): 4-28.

Pál J., Vörös A. (2011): Bevezetés a társadalmi kapcsolatháló-elemzés elméletébe és módszertanába. ELTE TÁTK Survey Szakest, Budapest http://surveyszakest.tatk.elte.hu/Pal_Voros.PDF letöltés dátuma: 2016.08.11

Popp J., Balogh P., Kovács S., Jámbor A. (2015): Hálózatosodás az agrárgazdaságtanban - Szerzői és hivatkozási kapcsolatok a Kelet-Közép-Európáról szóló szakirodalomban. Közgazdasági Szemle. 62 (5): 525-543.

Stokman, F. N. (2005): What Binds Us When with Whom? Content and Structure in Social Network Analysis. English version of Stokman, F. N. - Vieth, M. (2004) Was verbindet uns wann mit wem? Inhalt und Struktur in der Analyse sozialer Netzwerke, Kölner Zeitschrift für Soziologie. Sonderheft 44, 274-302.

Takácsné Gy. (1995): A családi gazdaságok méretére ható tényezők vizsgálata, különös tekintettel a növénytermesztés gépesítésére. Kandidátusi értekezés, Gödöllő.

Tóth Zs. (2009): 2.1.4. A hálózatelmélet alapfogalmai és rövid története in: Tudáshálók a gazdasági felsỏoktatásban PhD értékezés NYME-közgazdaságtudomyányi Kar, Sopron.

Williams, W. M. (1973): The social Study of family farming. In Mills, D. R. (ed), English Rusal Communities, London: Macmillan.

Yoshikane, F. - Nozawa T. - Tsuji, K. (2006): Comparative analysis of co-authorship networks considering authors' roles in collaboration: Differences between the theoretical and application areas. Scientometrics, 81 (2): 499-511. 